\title{
Marine molecular biology: An emerging field of biological sciences
}

Narsinh L. Thakur ${ }^{\mathrm{a}}$, Roopesh Jain ${ }^{\mathrm{b}}$, Filipe Natalio ${ }^{\mathrm{c}}$, Bojan Hamer ${ }^{\mathrm{d}}$, Archana N. Thakur $^{\mathrm{c}}$, and Werner E.G. Müller ${ }^{c, *}$

${ }^{a}$ National Institute of Oceanography, Dona Paula, Goa 403 004, India

${ }^{b}$ Department of Biotechnology, Dr H. S. Gour University, Sagar 470003, India

'Institut für Physiologische Chemie, Abteilung Angewandte Molekularbiologie, Universität Mainz, Duesbergweg 6, D-55099 Mainz, Germany; *Email: wmueller@mail.uni-mainz.de

dCenter for Marine Research, "Ruder Boskovic" Institute, HR-52210 Rovinj, Croatia.

Abstract: An appreciation of the potential applications of molecular biology is of growing importance in many areas of life sciences, including marine biology. During the past two decades, the development of sophisticated molecular technologies and instruments for biomedical research has resulted in significant advances in the biological sciences. However, the value of molecular techniques for addressing problems in marine biology has only recently begun to be cherished. It has been proved that the exploitation of molecular biological techniques will allow difficult research questions about marine organisms and ocean processes to be addressed. Marine molecular biology is a discipline, which strives to define and solve the problems regarding the sustainable exploration of marine life for human health and welfare, through the cooperation between scientists working in marine biology, molecular biology, microbiology and chemistry disciplines. Several success stories of the applications of molecular techniques in the field of marine biology are guiding further research in this area. In this review different molecular techniques are discussed, which have application in marine microbiology, marine invertebrate biology, marine ecology, marine natural products, material sciences, fisheries, conservation \& bio-invasion etc. In summary, if marine biologists and molecular biologists continue to work towards strong partnership during the next decade and recognize intellectual and technological advantages and benefits of such partnership, an exciting new frontier of marine molecular biology will emerge in future.

Keywords: Marine biology; Molecular biology; Marine microbiology; Marine natural products; Marine ecology; Fisheries 


\section{Introduction}

A revolution in biology has occurred as a result of recent advances in molecular biology, a field of science concerned with the study of chemical structures and processes of biological phenomenon at the molecular level. Despite its prominence in the contemporary life sciences, molecular biology is a relatively young discipline, originating in the 1930s and 1940s, and becoming institutionalized in the 1950s and 1960s. The field of molecular biology arose from the convergence of work by geneticists, physicists, and structural chemists on a common problem: the structure and function of the gene (Lindley and Tabery, 2005). While explaining the phenomena of life starting from the macromoleculs like nucleic acids and proteins, this discipline enabled numerous other fields to go molecular.

The ocean covers over $70 \%$ of the earth's surface and contains an extraordinary diversity of life. Our interest in understanding the function of marine ecosystems has been accelerated in recent years with growing recognition of their importance in human life. Marine biology is an interdisciplinary study of the life in the oceans, estuaries and inland seas of the world and this subject is on the threshold of an exciting new frontier of scientific discoveries and economic opportunities (Molecular biology in marine science, 1994). Marine biology intersects the field of biological oceanography, physiology, cell biology, biochemistry and molecular biology (Molecular biology in marine science, 1994). As molecular biology has great influence in the studies of marine ecosystems, it becomes important to review how molecular tools can be applied for the advances in the marine sciences.

The progress in the research of biological sciences happened during the past two decades with the development of sophisticated technologies and instruments (Molecular biology in marine science, 1994). However, the application of molecular techniques in marine biology has only recently begun to be appreciated. It has the potential of offering new capabilities to tackle problems associated with global climate changes, biodiversity, environmental quality and use of marine living resources (Molecular biology in marine science, 1994). Marine biologists study oceanic life in relation to marine environment that often range from small to global scale, whereas, molecular biologist study biological events in terms of the physiochemical properties of molecules. The immediate benefits 
of the collaborative research between these two disciplines could include improved management of fishery resources, enhanced production of useful species through aquaculture, isolation and development of natural products, better information about environmental degradation etc. (Molecular biology in marine science, 1994).

Recently, for example, a gene encoding a specific photopigment, rhodopsin, was discovered within a large fragment of DNA belonging to an as yet uncultured bacterium that is ubiquitous in the ocean. Recombinant expression and biochemical characterization showed that this is a new type of light-driven energy generation in the sea, which researchers never suspected before (Beja et al., 2000). The abundant pelagic bacteria that harbour this gene may be new types of phototrophs and that may alter the current perspective of complex energy flow systems in the sea. This discovery is an excellent example of how molecular biological approach in the field of marine biology can bring new insights to our vision of the function of marine ecosystems.

There are two different, but in some sense strictly related, trends through which genomic sciences can transform our knowledge of understanding marine biology. (1) Whole genome sequencing of key organisms and (2) analysis of partial or whole genome sequences from environmental samples (Cary and Chisholm 2001). Sequencing total genomes of many organisms is a rapidly advancing research area. In a major scientific breakthrough, researchers have decoded the first complete set of genetic instructions from a microorganism that confirms the existence of the third major branch of life on Earth. Researchers have sequenced the genetic information or "genome" of Methanococcus jannaschii, a single-cell microorganism known as an archaeon (meaning "ancient" in Greek) (Bult et al., 1996). This microbe is a methaneproducing thermophile discovered at the base of a Pacific Ocean thermal vent. This discovery provides fundamental information about life on Earth, its evolution and diversity. Recently the complete genome of Pelagibacter ubique was published showing that this microorganism is a clear example of genome streamlining (Giovannoni, 2005). Marine heterotroph $P$. ubique is the most successful free-living organism on the planet, accounting for around $25 \%$ of all microbial life. Unlike most other marine heterotrophs, it has a small genome $(1.3 \mathrm{Mb})$, in fact the smallest genome of any free-living cell in nature (Holden et al., 2005). 
Second approach is also very crucial in the study of marine life. Here, the environmental samples could be processed to analyze complete or partial genome sequences of marine organisms present in the samples. This approach provides novel insights into the ecology, evolution and metabolism of uncultured microorganisms in nature (Morris, 2006). Overall, both molecular approaches show great promise in making the genetic resources of several marine organisms more accessible.

\section{Applications}

\subsection{Marine microbiology}

Marine microbes have defined the chemistry of the oceans and atmosphere over evolutionary time (Redfield, 1958). Thousands of different species of bacteria, fungi and viruses exist in marine ecosystems comprising complex microbial food webs. These microorganisms play highly diverse roles in terms of ecology and biochemistry, in the most different ecosystems.

Marine environment is dominated by microscopic protists and prokaryotes. However, it is widely accepted that current and traditional culture based techniques are inadequate to study microbial diversity from environmental samples. Our understanding of marine microbial communities has increased enormously over the past two decades as result of culture independent phylogenetic studies (Fox et al., 1977). Recent advances in molecular techniques are adequate to describe the microbial diversity in a marine sample based on 16S rRNA sequence diversity. This approach has dramatically changed our perspective in the area of microbial diversity leading to the development of a database that describes microbial diversity at the genetic level (Ward et al., 1992; Hugenholtz, 1998; Hentschel et al., 2001). 16S rRNA gene, which is highly conserved in bacteria, has been selected as a marker gene for phylogenetic analysis (Amann and Ludwig, 2000). Taking advantage of the variation within 16S rRNA gene sequences of different bacterial species has driven a revolution in our knowledge in bacterial ecology over the last decade. The construction of $16 \mathrm{~S}$ rDNA library is labour intensive but it is in terms of phylogeny the most informative approach (Fig. 1), which has been applied to study the diversity of uncultured symbiotic bacteria (Hentschel et al., 2002). In a given complex sample, bacterial community DNA is extracted and 16S rRNA gene amplified 
by common PCR technique. The product is then cloned and expressed in host e.g. Escherichia coli followed by plasmid preparation of individual clones, reamplification of the 16S rRNA gene and sequencing. Several computer based programmes are now available for the construction of phylogenetic trees. For example TREE-PUZZLE is a computer program to reconstruct phylogenetic trees from molecular sequence data by maximum likelihood. It implements a fast tree search algorithm, quartet puzzling, that allows analysis of large data sets and automatically assigns estimations of support to each internal branch. TREEPUZZLE also computes pair wise maximum likelihood distances as well as branch lengths for user specified trees (Schmidt et al. 2002). The database of $16 \mathrm{~S}$ rRNA gene sequences is expanding rapidly, as new sequences are being added.

Molecular methods have also been applied in the identification of isolated fungi or to investigate fungi in environmental samples (Anderson and Cairney, 2004). The fungal identification is based on 18S rRNA gene and the internal transcribed spacer (ITS) region. However, compared to marine bacterial studies, very few reports exist regarding the application of molecular techniques to understand the diversity of marine fungi. Recently the genetics and molecular biology of marine fungi has been discussed in detail (Holley and Whitehead, 2006).

Several molecular tools are in use to study marine microorganisms and the application of Denaturing Gradient Gel Electrophoresis (DGGE) is one of them. This technique is widely used to detect the phylogenetic "fingerprint" of diverse marine microorganisms (Taylor et al., 2004; Taylor et al., 2005; Li et al., 2006). As an example, DNA is extracted from marine sponge and bacteria specific 16S rRNA gene is amplified by using precise primers. The resulting PCR fragments are separated on polyacrylamide gel with an increasing denaturing gradient (Fig. 2). In this case, each DGGE band represents a single 16S rRNA gene amplified sequence. Thus each lane stands for a specific fingerprint of a microbial community at a certain given time. In a further step, individual bands can be excised, reamplified and sequenced to obtain phylogenetic information.

Another important molecular tool is Fluorescence In situ hybridization (FISH), which has proved to be invaluable in research and diagnosis to visualize the expression of 
nucleic acids in their cellular environment (Speel et al., 1999). This technique enables precise localization and identification of individual cells that contain a specific nucleic acid sequence in preserved chromosomes, cells or tissue sections. This technique also confirms the presence and abundance of a given isolate in its natural environment (Friedrich et al., 2001). The detection of functional genes similar to genes of well known species could help in the characterization of largely un-described microbial species with respect to its ecological and biochemical roles in the marine environment. Molecular approach has also been used to detect the genes responsible for the production of different enzymes in marine bacteria (Ramaiah et al., 2000a and 2000b). In addition to this, the genome analysis of marine microorganisms facilitates the use of highly specific genes with biotechnological applications such as production of the so called cell factories and bio-indicator strains as well as identification of new drug.

Metagenomics or the culture-independent genomic analysis of an assemblage of microorganisms has the potential to answer fundamental questions in microbial ecology (Riesenfeld et al., 2004). One approach that has offered very useful information at the genome level is the massive marine prokaryotic metagenome-sequencing project, which is providing a tremendous database for discovering metabolic capabilities and new ways to conceptualize and study prokaryotic biodiversity (Falkowski and de Vargas, 2004). Environmental genomics is also revealing bacterial interactions with marine animals, and its influences on animal populations and ecosystem function (Thakur and Müller, 2005). A recent study discovered 430 novel bacterial ribotypes associated with three coral species. In this investigation, the shifts in bacterial species composition appear to trigger coral health and disease (Azam and Worden, 2004). The massive marine metagenome-sequencing project conducted at the Sargasso Sea near Bermuda has provided information at the genome level (Venter et al., 2004). In this project "wholegenome shotgun sequencing" method was applied to elucidate the gene content, diversity, and relative abundance of the organisms within these environmental samples. Some 1800 new uncultured marine prokaryotic species, including 148 previously unknown bacterial phylotypes have been estimated from 1500 litre of oligotrophic seawater. In this study over 1.2 million previously unknown genes have been identified, including more than 782 new rhodopsin-like photoreceptors. This project demonstrated 
that shotgun sequencing provides a wealth of phylogenetic markers that can be used to assess the phylogenetic diversity of a sample with more power than conventional PCRbased rRNA studies allow (Venter et al., 2004).

There is growing evidence for the existence and importance of different families of ePK-like kinases (ELKs) in bacterial signaling, though it is thought to occur through structurally unrelated histidine kinases. In a recent publication, analysis of the Global Ocean Sampling (GOS) dataset reveals that ELKs are as prevalent as histidine kinases and may play an equally important role in prokaryotic behavior (Kannan et al., 2007). In this study, researchers explored huge phylogenetic and functional space to cast light on the ancient evolution of these ePK-like kinases and opined that this diverse superfamily serves as a model for further structural and functional analysis of enzyme evolution.

In the study of environmental microbiology, DNA microarray technology has also been introduced. In a recent review, Wagner and co-workers summarized the state-ofthe-art of using microarray approaches in microbial ecology research and discuss in more detail crucial problems and promising solutions. The authors have also outlined very likely scenarios for an innovative combination of microarrays with other molecular tools for structure-function analysis of complex microbial communities (Wagner et al., 2007). Molecular techniques have also been used to examine symbiotic relationships between marine invertebrates and bacteria. Several recent studies have sought to address the phylogenetic diversity of microbial communities associated with marine sponges by using 16S rRNA gene sequence analysis (Lopez et al., 1999; Webster et al., 2001; Hentschel et al., 2002; Webb and Maas, 2002; Thakur et al., 2003). By using this tool a new candidate phylum named 'Poribacteria' has recently been proposed to acknowledge the specific affiliation of some new bacteria with sponges, (Fieseler et al., 2004). The molecular phylogenetic surveys of native microbial assemblages showed the specific association of a single Crenarchaeal phylotype with marine sponge host species. This association was claimed to be the first described symbiosis involving Crenarchaeota (Preston et al., 1996). Curiously, some studies have shown that the viruses are abundant in the oceans and they play an important role in the marine ecosystem (Culley et al., 2003). Efforts are underway to study these marine viruses with the help of molecular techniques, as they offer tremendous potential for biotechnology 
as cloning vectors, providing a vehicle to move selected pieces of DNA into a target organism.

Oceans contribute about half of the global annual primary production, a process by which carbon dioxide $\left(\mathrm{CO}_{2}\right)$ is converted into organic carbon by phytoplankton. Until recently, most of our knowledge about marine phytoplankton was derived from net samples and bulk process measurements, such as chlorophyll $a$ and $\mathrm{C}^{14}$ biomass estimation. Molecular approach has been applied to study marine phytoplankton also through the use of immunological and nucleic acid detection probes to understand, for example the phenomenon of phytoplankton bloom and also the effects of environmental stress on phytoplankton growth rate (Roche et al., 1999). New molecular approaches to monitor harmful algal blooms in the water column have been established recently by techniques such as the sandwich hybridization assay (Babin et al., 2005).

Diatoms are a ubiquitous class of microalgae of extreme importance for global primary productivity in the Oceans, as they contribute as much as $25 \%$ of the primary production on earth (Van den Hoek et al., 1997). Diatoms are brown algae belonging to the division of Heterokonta and are thought to have arisen from a secondary endosymbiosis between a red algae (Rhodophyta) and a heterotrophic flagellate related to the Oomycetes around 300 million years ago (Gibbs, 1981; Medlin et al., 2000) Diatoms are not only extremely important microorganisms for marine and freshwater environments but also for biotechnology as essential feeding component in aquaculture and source of several valuable products such as pigments as in Chrysophyta, or the volatile polyunsaturated aldehydes (PUAs) that in analogy to plants seem to employ these molecules for defence (Miralto et al., 1999) and oxylipins as activators of the fatty acid metabolic pathway as signal transduction molecules associated with important physiological and pathological processes (Cutignano et al., 2006). The development of a nuclear genetic transformation system, using microparticle bombardment for the diatom Phaeodactvlum tricornutum allowed the introduction of the sh ble gene from Streptoalloteichus hindustanus into cells. The sh ble gene encodes a protein that confers 10 times more resistance to the antibiotic Zeocin when compared with the wild type. The successful system provides the tools necessary for dissecting gene structure and regulation and introducing novel functions in to diatoms (Apt et al., 1996). 
The annotation of full diatom genomes was published recently for Thalassiosira pseudonana (Armbrust et al., 2004) and Phaeodactylum tricornutum (Scala et al., 2002). Diatoms became powerful genomic and post-genomic technology platforms. For example, Phaeodactlvum tricornutum is an excellent model due to its reduced genome size short generation time and ease of genetic transformation (Scala et al., 2002). The generation of cDNA catalog for this diatom species can inform researchers about the functional and phylogenetic expressed genes within a particular population and moreover the discovery of new metabolic routs through EST-sequences. Application of molecular techniques presents a quantitative framework through which the diversity, evolution and metabolism of marine phytoplankton population can be analyzed. The population genetic consequences of drifting and resident plankton copepods in Norwegian fjords have also been examined by using molecular tools (Bucklin et al., 2000)

\subsection{Marine invertebrate biology}

Most of the animal phyla are either exclusively or predominantly marine but these organisms are not investigated extensively from their biological point of view. Researchers are concentrating on few marine model organisms like sponges, corals, sea urchins, tunicates etc. to study their biological features. Using molecular techniques, investigators aimed to use marine animals as biological models to study morphological development within the context of chordate evolution.

In this regard, marine sponges (Porifera) have attracted significant attention from various scientific disciplines. Sponges (Porifera) form the basis of the metazoan kingdom and have been reported to be the evolutionary most ancient phylum still extant. Until recently, it was still unclear whether sponges are provided with a defined body plan. Only after the cloning, expression and functional studies of characteristic metazoan genes it has been proven that sponges are not to be merely recognized as primitive cell aggregates but already complex animals provided with a defined body plan (Müller et al., 2003). Sponge evolution (approximately 600-800 Mya) was elucidated based on cDNA sequence similarities for example, between galectin molecules from different organisms and metazoan (Hirabayashi and Kasai, 1993; Pfeifer et al., 1993). 
Few years ago, who would have expected that the majority of sponge proteins would be found to be significantly more similar to human sequences than to those from $C$. elegans (Gamulin et al., 2000). The analysis of the sponge genome allowed us to pinpoint the evolutionary mechanism which was occurred approximately 600-800 Mya.

Since last few years, marine molecular biologists are working on a sponge genome project, which will significantly contribute to the understanding of the evolution of the molecular mechanisms of metazoan genes and moreover human diseases (Müller et al., 2003). Analysis of genome organization in marine sponges is a completely novel approach and it led to the elucidation of selected genes and gene arrangements that exist in gene clusters (e.g. receptor tyrosine kinase cluster and the allograft inflammatory factor cluster). Most of these studies were performed with sponges as model organisms, such as Suberites domuncula and Geodia cydonium (Demospongiae), Aphrocallistes vastus (Hexactinellida) and Sycon raphanus (Calcarea) (Müller et al., 1984; Wiens et al., 1999; Müller et al., 2001; Thakur et al., 2005).

Another relevant marine organism is the sea urchin (Phylum Echinodermata), Class Echinoidea) that has its historical place in studies of development, gene regulation and systems biology (Davidson et al., 2002). It has been used for long time as embryogenesis standard model (Qiao et al., 2003). Moreover, it was also used in conjunction with gene knock-out studies (Bogarad et al., 1998). It is known that sea urchin development of a body plan is controlled by large networks of more than 40 regulatory genes. The interactions among genes producing transcription factors and signalling components, that in overall controls the specification of endoderm and mesoderm in embryo through a complex combination creating a huge challenge for future scientists from the most diverse fields from molecular biologist, embryologist until bioinformatics illuminating basic developmental process in animals. Despite the fact that network analysis is still in a very early stage, some interesting results are emerging (Davidson et al., 2003). Recently the purple sea urchin (Strongylocentrotus purpuratus) genome was published as the first nonchordate deuterostome sequence (Sea urchin genome sequencing consortium 2006). The sea urchin genome reveals large domains of unexplored biology, shedding light over the mechanisms of cell generation and their fate, thus contributing significantly towards a complete understanding of the genomic 
regulatory system and its architecture. Gene expression array technology has been used to study echinoderm development in the sea urchin Strongylocentrotus purpuratus (Rast et al., 2000; Rast et al., 2002). Microarray studies have been carried out to investigate development in Urochordate, as this group represents a quite simple model to study gene networks when compared with vertebrates (Azumi et al., 2003a). Nevertheless, micro and macroarray technologies have been applied to study adaptations of marine organisms to environmental changes and also to check tolerance or stress responses to pollutants (for more details see reference Wilson et al., 2005).

Molecular techniques were also applied to investigate the evolution of chordate development, with special focus on the tunicate subphylum. A remarkable characteristic of tunicates is their small, compact genomes, having size of 160 megabases (Mb) (Simmen et al., 1998). The miniature tunicate genome may be an ancestral chordate feature, which persists in tunicates because of strong selective pressure for rapid development. In order to study vertebrate immune system this particular marine group provides valuable information through genomic analysis (Rast et al., 2006; Azumi et al., 2003b). It was found that the sea urchin has an unprecedented complexity of innate immune recognition receptors relative to other animal species yet characterized. The findings serve to underscore the dynamic utilization of receptors and the complexity of immune recognition that may be basal for deuterostomes and predicts features of the ancestral bilaterian form (Rast et al. 2006).

Several papers have been published on the completion of the nuclear genome sequences for the Metazoans Drosophila malanogaster, Caenorhabtitis elegans, Homo sapiens, Mus musculus etc. Comparatively, very few resources have been allocated for the study of marine metazoans (Wilson et al., 2005). So far, the genomes of five marine metazoan animals have been completely sequenced (or are about to be finished), which includes puffer fish (Fugu rubripes) (Aparicio et al., 2002), ascidians (Ciona intestinalis and Ciona savignyi) (Kim et al., 2007), an appendicularian (Oikopleura dioica) (Seo HC et al., 2001) and an Echinoderm (sea Urchin). As new high-throughput sequencing technologies are being introduced in the field of genomic analysis and the number of bioinformatics tools are available for the investigation, one can predict that in the coming years more marine organisms will be studied at their genomic level. 
In most of the marine invertebrates, larval recruitment is the key event of their life cycle. To understand the population dynamics of marine invertebrates, it is necessary to distinguish among larvae of different species, but this is not always possible Molecular taxonomic techniques have the power to advance the understanding of the larval ecology of these species. A geographical survey of genetic variation provides an indirect means of tracing movements made between marine populations of larvae and other propagules. Genetic markers can also help to provide strong evidence that populations are closed (self-recruiting) because their genetic differentiation is highly sensitive to migration (Hellberg et al., 2002). Nucleic acid-based sandwich hybridization assays have been applied successfully to detect, for example, barnacle larvae in the water column (Goffredi et al., 2006). The adoption capacity of this technology promises to have further applicability for the various organisms and could be useful to understand larval ecology in the world's oceans.

Nucleic acid concentration and the RNA/DNA ratio have been utilized as biochemical indicators of the metabolic state and growth of a variety of marine organisms. Under this aspect, experiments were carried out to check the influence of rearing temperature and food concentration on barnacle Balanus amphitrite larvae by estimating nucleic acid concentration (Anil et al., 2001). Since barnacles are the major cause of fouling, these studies are of special importance in marine biofouling research. Recently developed fluorescence techniques were used to quantify RNA and DNA content in the whole body of fed and starved hatchery-reared larval and juvenile Japanese flounder (Paralichthys olivaceus). Other studies performed on natural seawater and sediment samples have been undertaken to investigate the relationships between RNA/DNA ratio and the metabolic state of the microbial communities associated with suspended and sedimentary organic particles (Dell'Anno et al., 1998).

The physiological, biochemical and genetic processes of individual organisms are most sensitive to environmental stress and these processes have significant repercussions into population and ecosystem-level changes. In this regard, the genetic features of key marine organisms will illuminate the biology of these organisms by providing more information about different processes. 


\subsection{Marine ecology}

The genetic tools have shown to be of great significance in addressing novel questions in the fields of ecology. Environmental genomics or ecogenomics focus on responses to environmental variation and biological interactions in space and time at the genomic level (Chapman, 2001). Marine organisms, in general, have not been studied as extensively as their terrestrial counterparts, although studies of marine organisms have made major contributions to our fundamental understandings of ecological factors such as keystone species, predation and competition (Molecular biology in marine science, 1994). Marine biologists have led the study of ecological interactions for several decades, but molecular techniques have been introduced recently in this field giving significant advances in our comprehension of complex systems of modes of action. Understanding the control of spatial and temporal distributions of marine organisms is becoming increasingly important as we attempt to determine how natural and humancaused environmental changes affect population sizes, extinction and invasion of new species. The need for such information is obvious for commercially important species as well as other species, which hold vital roles in the ecosystem. The applications of different molecular tools in the field of marine ecology have been discussed by several researchers (Burton, 1996; Rocha-Olivares, 1998).

\subsection{Marine natural products}

Marine organisms comprise approximately half of the total biodiversity on the earth and the marine ecosystem is the greatest source to discover useful therapeutics (Blunt et al., 2005; Faulkner, 2002). Sessile marine invertebrates such as sponges, bryozoans, tunicates, mostly lacking morphological defence structures have developed the largest number of marine derived secondary metabolites including some of the most interesting drug candidates (Newman and Cragg, 2004; Sipkema et al., 2005; Mayer and Gustafson, 2006; Mayer et al., 2007; Tan, 2007). In recent years, a significant number of novel metabolites with potent pharmacological properties have been discovered from the marine organisms. Although there are only few marine-derived products currently in the market, several marine natural products are now in the clinical pipeline, with more 
undergoing development (Haefner, 2003; Rawat et al., 2006). While primary approaches are still made within the academic laboratories, research activities are currently being extended into the R\&D departments of pharmaceutical companies. The research has generated convincing evidences that marine natural products have an exceedingly bright future in the discovery of life saving drugs.

The development of molecular biology field and recent progress of new technologies such as genetic engineering and bioactivity screening offer a unique opportunity to establish marine natural products as drug leads. There are several examples of recent advances in the application of these technologies to the discovery and development of novel drugs from marine origin. Some of the examples showing impact of molecular biology in marine natural products research are discussed below.

Molecular identification (16S and 18S rRNA gene analysis) of marine microorganisms having bioactive potential gave major breakthrough in the screening of microbial libraries for drug discovery by avoiding replication of microbes during exploration. Restriction Fragment Length Polymorphism (RFLP) is a technique in which organisms may be differentiated by analysis of patterns derived from cleavage of their DNA. If two organisms differ in the distance between sites of cleavage of a particular restriction endonuclease, the length of the fragments produced will differ when the DNA is digested with a restriction enzyme. The similarity between the patterns generated can be used to differentiate species (and even strains). RFLP study is also possible with the amplified PCR product of bacterial genes. The presence or absence of fragments, resulting from changes in recognition sites, is used to identify species or populations. This technique has been shown to be very helpful in microbial de-replication studies in marine microbial drug discovery programs (Fig. 3).

Marine bacteria belonging to the order Actinomycetales have been identified as producer of a wide range of natural products. In last two decades, the combination between the fast development of molecular tools for genetic manipulation of Actinomycetes and an explosive growth in sequence information for known and orphan biosynthetic gene clusters has led to a deeper understanding of the genetics and biochemistry of secondary metabolite biosynthesis (Li and Piel, 2002). 
The discovery and development of an array for novel bioactive compounds through metagenomic cloning and expression has proven that this technology is an excellent alternative for exploiting uncultivable terrestrial microbes for natural product drug discovery (Rondon et al., 2000; Donadio et al., 2002; Keller and Zengler, 2004). Similar work has been conducted targeting uncultivable microbes of marine sediments and sponges using metagenomic-based techniques to develop recombinant secondary metabolites (Kim et al., 2005; Moreira et al., 2004; Li and Qin, 2005) (Fig. 4). It is still too early to make any prediction or conclusion about metagenomics-based drug discovery, which will remain one of the most active research fields for reaping the fruit of marine microbial diversity. 'However, the genomic libraries generated through metagenomic approaches would provide very useful molecular information for genetic conservation studies and the sustainable maintenance of marine microbial diversity. These could be important resources for our own survival in the long term from the threats posed by global warming, environmental deterioration and other disastrous environmental phenomena.

Recently, the use of high-throughput genome scanning for analyzing gene cluster involved in the natural-product biosynthesis has been highlighted. Polyketide synthases (PKSs) are a class of enzymes that are involved in the biosynthesis of secondary metabolites such as erythromycin, rapamycin, tetracycline, lovastatin and resveratrol (Gokhale and Tuteja, 2001). Several researchers have successfully isolated polyketide biosynthetic genes from marine bacteria and fungi, which have been cloned, sequenced and expressed in heterologous hosts. Bioactive bryostatins, complex polyketides were isolated from the marine bryozoan Bugula neritina, but recent studies indicate that they are produced by the uncultured symbiotic bacterium "Candidatus Endobugula sertula". In this investigation, putative Bryostatin Polyketide Synthase Gene Cluster was identified in a bacterium. The heterologous expression of this biosynthetic gene cluster has the potential of producing the bioactive bryostatins in large enough quantities for development into a pharmaceutical (Sudek et al. 2007). Some marine sponge associated bacteria with antimicrobial assets are perceived to have polyketide synthases gene clusters and investigation is underway to explore them (Müller et al. unpublished). By using molecular biology approach, polyketide biosynthesis responsible 
for the production of antitumour molecules by an uncultivated bacterial symbiont of the marine sponge Theonella swinhoe has been explored (Li and Piel, 2002). Efforts are underway to identify, analyze and express a set of genes present in the genome of marine organism that encodes a chain of enzymes, which ultimately synthesize the bioactive compounds. Following the knowledge provided by nature, efforts are being made also to synthesize desired compounds in genetically engineered organisms through transfer of biosynthetic gene clusters from sponge to bacteria (A group at University of Mainz, Germany is currently working in this field). Another important biosynthetic pathway involves non-ribosomal peptide synthases (NRPS) gene cluster have also been reported in marine organisms (Moore 2005; Ehrenreich et al., 2005).

Recombinant DNA (rDNA) technology has made a revolutionary impact in the area of human healthcare by enabling mass production of safe, pure and effective recombinant products. Natural compounds extracted from marine organisms showed to be exceptionally promising for the treatment of cancer, inflammation and infectious diseases. However, obtaining a large-scale supply of these complex natural chemical structures for worldwide use has been environmentally unsound and economically unviable. In view of this rDNA technology allows efficient exploration of marine organisms for drug discovery. Recently, researchers from Australian Institute of Marine Science (AIMS) and London School of Pharmacy demonstrated that shotgun cloning and heterologous expression of the Patellamide Gene Cluster is a good strategy to achieve sustained production of anticancer metabolites, Patellamides (Long et al., 2005). The patellamide gene cluster is cloned from Prochloron sp., a photosynthetic endosymbiont of the ascidian Lissoclinum patella (Urochordata). A recent compilation of natural-product-derived compounds from marine sources, currently in advanced clinical trials such as potent antitumor substance discodermolide, demonstrated that molecular biology would have great impact on the future of marine drug discovery programs.

\subsection{Material sciences}

Biosilicification, the biological formation of opal-like amorphous hydrated silica, occurs on a globally vast scale in a wide variety of organisms, including diatoms, sponges, molluscs, and higher plants (reviewed in Bäuerlein, 2004). Biomineralization, 
biosilicification in particular (i.e. the formation of biogenic silica, $\mathrm{SiO}_{2}$ ), has become an exciting source of inspiration for the development of novel bionic approaches following "nature as model". Siliceous sponges are unique among silica forming organisms in their ability to catalyze silica formation using a specific enzyme termed silicatein (reviewed in Weaver and Morse 2003). By using different molecular biological techniques, the role of silicatein in the formation of silica in different sponge species has been investigated. The first complete silicatein complementary DNA (cDNA) was cloned from Tethya aurantium (Shimizu et al., 1998) and later from S. domuncula (Krasko et al., 2000).

Recently, at least two silicatein isoforms have been identified in several sponge species. The genes/cDNAs encoding two isoforms of silicatein, the $\alpha$ - and $\beta$-form, have been characterized from various marine sponges, including $T$. aurantium (Shimizu et al., 1998; Cha et al., 1999), S. domuncula (Krasko et al., 2000) and P. ficiformis (Pozzolini et al., 2004), where as at least four isoforms of silicatein -a (silicatein $\alpha 1$ to a4) have been identified in the fresh water sponge Lubomirskia baicalensis (Kaluzhnaya et al., 2005; Wiens et al., 2006). Lately, silicatein cDNA was also obtained from the fresh water sponge E. fluviatilis (Funayama et al., 2005).

Silica is widely used in industry and medicine, e.g. for the fabrication of glasses, ceramics, paints, adhesives, catalysts and photonic materials, as a component of molecular sieves and other separation materials, and as a food additive, carrier (e.g. in washing powders), stabilizer (e.g. in tooth paste) and for filling (e.g. in rubber industry), as well as an insulator in semiconductor devices. Silica is also an important material in nano (bio)technology. The technological production of silica mostly requires high temperature conditions and extremes of pH (Tolbert et al., 1997; Stober et al., 1968). At lower temperatures, silica can also be produced by sol-gel processes (reviewed in Brinker and Scherrer, 1990; Hench and West, 1990).

\subsection{Fisheries}

Genome studies of different commercially important fish and the genetic variability of their populations has been reviewed earlier (Molecular biology in marine science, 1994). Such information is essential for effective management of oceanic fish populations. These studies demonstrate the promise of molecular techniques for addressing 
questions that were previously difficult to answer. The studies regarding the genetic variability of commercially harvested fishes like salmon and tuna have demonstrated that new mitochondrial and nuclear DNA technologies will permit a definition of population structure, identification of stocks and quantification of gene flow (Molecular biology in marine science, 1994).

Genetic variation in skipjack tuna Katsuwonus pelamis (L.) was investigated using PCR-RFLP analysis of the mitochondrial DNA D-loop region (Menezes 2006). The results showed high level of genetic diversity within a population of $K$. pelamis from India and Japan. The identification of essentially self-recruiting populations as units for fisheries management is a prerequisite for the conservation and sustainable utilization of fish biodiversity. Molecular markers have been shown to be particularly useful in freshwater and anadromous species, most notably in the assessment of mixed stock fisheries and the assessment of stocking. However, molecular markers can also be used to investigate genetic changes caused by over fishing and "stock collapses" (Carvalho and Hauser, 1999).

Previously, researchers in the field of quantitative genetics relied primarily on statistical approaches, large scale breeding projects and common-garden experiments to tease apart the genetic and environmental components of fitness traits. The field has expanded recently following the development of a wide range of molecular genetic tools (motivated to a large degree by advances in the human genome project) that can be used to locate the genetic loci underlying these traits. Now genome-mapping approaches are in use to find markers linked to gene loci involved in fitness traits such as growth, age at maturity and disease resistance in Pacific salmon (Naish and Park, 2002). These markers are useful tools in understanding the genetic diversity underlying these adaptive traits in salmon populations and in using predictive approaches to answering many of the questions raised above.

For decades, genetic intervention has been used to enhance animal and plant agriculture production. These techniques are now being applied to aquatic animals in an effort to overcome many different production challenges. Aquaculture is an important part of the economy of several countries. Both traditional techniques as well as molecular biological tools are being used to develop aquaculture. Novel genetic 
technologies involving the use of DNA based tools are also under development for a range of aquaculture species. Genetic improvement of aquaculture species offers a substantial opportunity for increased production efficiency, health, product quality and, ultimately, profitability in aquaculture enterprises (Davis and Hetzel, 2000). These gene marker technologies can be used for identification and monitoring of lines, families and individuals, monitoring and control of inbreeding, diagnosis of simply inherited traits and genetic improvement through selection of favourable genes and gene combinations. Aquaculture often relies on wild population for brood stock. The application of genomics in this area helps to identify and select elite brood stock, which is fast growing, healthy and of high quality. In short, aquaculture genetics shows immense potential for enhancing production in a way that meets aquaculture development goals for the new millennium.

\subsection{Conservation and bio-invasion}

Molecular markers provide valuable information on the status and the significance of endangered species and populations, and thus are vital for the identification of conservation priorities (Haig, 1997). Conservation efforts are directed towards minimizing extinction risks and genetic approaches assist these efforts in a large number of ways (Molecular biology in marine science, 1994). Numbers of molecular and quantitative genetics approaches have been combined to investigate and protect endangered marine species. Molecular genetic characterization of endangered and threatened species including cetaceans and sea turtles has allowed better definition of population structures, genetic diversity and variability (Molecular biology in marine science, 1994).

Marine bioinvasion is the introduction of marine organisms alien to local ecosystem through ship hulls and ballast water. This process has serious consequences to native biota, fishery and general coastal ecosystem (Anil et al., 2002). Molecular biology approach can surely be applied in the investigation of bio-invasion as well as in the finding economical and environmental viable solutions for this problem. The research in this area involves the development and testing of molecular probes for the detection of alien organisms in ballast water. For the reliable monitoring of ships ballast, specific 
nested PCR-based tests for detection of the harmful species in environmental and ballast water samples have been developed recently (Deagle et al., 2003).

\subsection{Biofouling and bioremediation}

Characterization of biofilm structure using molecular approaches offer considerable potential for finding novel biofouling prevention strategies. Molecular techniques highlight the deficiencies of culture methods in identifying biofilm producing bacteria; hence, strains with the most impact on settlement of spores and larvae may not yet have been isolated and cultured. In view of this, new molecular tools provide the opportunity to improve our fundamental understanding of the interactions between fouling organisms and biofilms formation, which in turn will lead to novel strategies to control biofouling.

Bioremediation shows great promise for addressing problems in marine environments and in aquaculture. These problems include catastrophic spills of oil in harbors and shipping lanes and around oil platforms; movement of toxic chemicals from land, through estuaries, into the coastal oceans; disposal of sewage sludge, bilge waste, and chemical process wastes, etc. During the last decades, major advances have been made in understanding the mechanisms of interactions between microorganisms and pollutants and in the application of specialized microorganisms for the in situ and ex situ treatment of organic xenobiotics, heavy metal and oil. Molecular biological methods for the identification and characterization of bacteria and their specific properties have been used to assess the composition and activity of microbial communities at contaminated sites (Geets et al., 2003). Molecular and microbial monitoring tools, combined with pilot studies have proved to be effective in bioremediation strategy.

Molecular biology has great impact in the analysis of environmental quality as well. The ocean has been and will continue to be unfortunately used for disposal of human wastes. In view of this, molecular probes and enzymatic tests may provide a rational basis to regulate the ocean disposal of industrial sludge, sewage or radioactive substances. The expression of genes that respond to environmental stresses, such as changes in temperature, oxygen and pollution (e.g. genes encoding heat shock proteins, cytochrome $\mathrm{P} 450$, metallothionein and proteins) can potentially provide excellent 
sublethal indicators that could be used to monitor the impact of oceanic dump sites and other pollution problems (Molecular biology in marine science, 1994).

\section{Summary and outlook}

Marine molecular biology is a discipline, which strives to define and solve the problems regarding the sustainable exploitation of marine life for human health and welfare, through the cooperation between scientists working in marine biology, molecular biology, microbiology and chemistry. Such collaboration is now going on successfully in several laboratories world wide. Several pioneering success stories of the application of molecular techniques in the field of marine biology are guiding further research in this area. In order to strengthen these efforts, appropriate infrastructures are necessary combined with new technologies for their use in molecular biology. A mechanism is also needed to promote collaborative partnership of academic marine scientists with private industry and to permit appropriate research findings on marine organisms to be transferred rapidly to the private sector for commercialization. If marine biologists and molecular biologists can continue to work towards strong partnership during the next decade and recognize intellectual and technological advantages and benefits of such partnership, an exciting new frontier of marine molecular biology will successfully emerge in a close future.

\section{Acknowledgements}

The report Molecular biology in marine science: scientific questions, technological approaches and practical implications. (National Academy Press, Washington, D.C. 1994), prepared by Committee on molecular marine biology, Ocean studies board, National research council, Washington DC 20418, USA has been extensively referred, to write this review article. NLT is thankful to the Director, NIO, Goa and Dr. C. G. Naik, NIO, Goa for support and encouragement. We are also grateful to our colleagues from The Centre of Excellence "BIOTECmarin". (Bundesministerium für Bildung und Forschung project), Germany. Finally, we wish to thank the anonymous referees for their useful comments. This is a NIO contribution (\#...................). 


\section{References}

Amann R, Ludwig W. Ribosomal RNA-targeted nucleic acid probes for studies in microbial ecology. FEMS Microbiol Rev 2000;24:555-65.

Anderson IC, Cairney JWG. Diversity and ecology of soil fungal communities: increased understanding through the application of molecular techniques. Environ Microbiol 2004;6:769-79.

Anil AC, Desai DV, Khandeparkar L. Larval development and metamorphosis in Balanus amphitrite darwin (Cirripedia; Thoracica): Significance of food concentration, temperature and nucleic acids. J Exp Ma. Biol Ecol 2001;263:125-41.

Anil AC, Venkat K, Sawant SS, DileepKumar M, Dhargalkar VK, Ramaiah N, et al. Marine bioinvasion: Concern for ecology and shipping. Curr Sci 2002;83:214-8.

Aparicio S, Chapman J, Stupka E, Putnam N, Chia JM, Dehal P. Whole-genome shotgun assembly and analysis of the genome of Fugu rubripes. Science. 2002;297:1283-1285.

Apt E, Grossman AR, Kroth-Pancic PG. Stable nuclear transformation of the diatom Phaeodactylum tricornutum, Mol Gen Genet 1996;252:572-9.

Armbrust EV, Berges JA, Bowler C, Green BR, Martinez D, Putnam NH, et al. The genome of the diatom Thalassiosira pseudonana: ecology, evolution, and metabolism. Science 2004;306:79-86.

Azam F, Worden AZ. Oceanography: microbes, molecules, and marine ecosystems. Sci 
2004;303:1622 -4.

Azumi K, Santis RD, Tomaso AD, Rigoutsos I, Yoshizaki F, Pinto MR, et al. Genomic analysis of immunity in a Urochordate and the emergence of the vertebrate immune system: "waiting for Godot". Immunogenet 2003a;55:570-81.

Azumi K, Takahashi H, Miki Y, Fujie M, Usami T, Ishikawa H, et al. Construction of a cDNA microarray derived from the ascidian Ciona intestinalis. Zool Sci 2003b;20:122-9.

Babin M, Cullen JJ, Roesler CS, Donaghay PL, Doucette GJ, Kahru M, et al. New approaches and technologies for observing harmful algal blooms. Oceanography 2005;18:210-27.

Bäuerlein E. Biomineralization, progress in biology, molecular biology and application. Wiley-VCH, Weinheim 2004.

Beja O, Arvind L, Koonin EV, Suzuki MT, Hadd A, Nguyen LP, et al. Bacterial bacteriorhodopsin: evidence for light driven proton pumping in the sea. Sci 2000; 289:1902-6.

Blunt JW, Copp BR, Munro MHG, Northcote PT. Prinsep MR. Marine natural products Nat Prod Rep 2005;22:15 - 61.

Bogarad LD, Arnone M I, Chang C, Davidson EH. Interference with gene regulation in living sea urchin embryos: Transcription factor Knock Out (TKO), a genetically controlled vector for blockade of specific transcription factors. Proc Natl Acad Sci USA 1998; 95:14827-32. 
Brinker CJ. Scherrer GW. Sol-Gel Science: The Physics And Chemistry Of Sol-Gel Processing, Academic, London, 1990.

Bucklin A, Kaartvedt S, Guarnieri M, Goswami U. Population genetics of drifting (Calanus spp.) and resident (Acartia clausi) plankton in Norwegian fjords. J. Plankton Res 2000;22:1237-1251.

Bult CJ, White O, Olsen GJ, Zhou L, Fleishman RD, Sutton GG. Complete genome sequence of the methanogenic archeon,Methanococcus jannaschii;Science 1996;273:1058-1073.

Burton RS. Molecular tools in marine ecology. J Exp Mar Biol Ecol 1996;1200:85-101

Carvalho GR, Hauser L. Molecular markers and the species concept: new techniques to resolve old disputes? Rev Fish Biol Fish 1999;9:379-82.

Cary SC, Chisholm SW. Ecological genomics: The application of genomic sciences to understanding the structure and function of marine ecosystems. Report, NSF workshop on Marine Microbial Genomics. University press. 2001; Pp. 1-20.

Cha JN. Shimizu KK. Zhou Y. Christiansse SC. Chmelka BF. Stucky GD. Morse DE. Silicatein Filaments And Subunits From A Marine Sponge Direct The Polymerization Of Silica and Silicones in vitro. Proc Natl Acad Sci USA 1999;96:361-365.

Chapman RW. EcoGenomics - a consilience for comparative immunology. Dev Comp Immunol 2001;25:549-51.

Culley Al, Lang AS, Suttle CA. High diversity of unknown picorna-like viruses in the sea. Nature 2003;424:1054-7.

Cutignano A. d'Ippolito G. Romano G. Lamari N. Cimino G. Febbraio F. Nucci R. Fontana 
A. Chloroplastic Glycolipids Fuel Aldehyde Biosynthesis in the Marine Diatom Thalassiosira rotula. ChemBioChem 2006;7:450 - 456.

Davidson E H, Rast JP, Oliveri P, Ransick A, Calestani C, Yuh $\mathrm{CH}$, et al. A genomic regulatory network for development. Science 2002;295:1669-78.

Davidson EH, McClay DR, Hood L. Regulatory gene. networks and the properties of the developmental process. Proc Natl Acad Sci USA 2003;100:1475-80.

Davis GP, Hetzel DJS. Integrating molecular genetic technology with traditional approaches for genetic improvement in aquaculture species. Aqua Res 2000;31:3-10.

Deagle BE, Bax N, Hewitt CL, Patil JG. Development and evaluation of a PCR-based test for detection of Asterias (Echinodermata: Asteroidea) larvae in Australian plankton samples from ballast water. Mar Freshwater Res 2003;54:709 - 19.

Dell'Anno A, Fabiano M, Duineveld GCA, Kok A, Danovaro R. Nucleic acid (DNA, RNA) quantification and rna/dna ratio determination in marine sediments: comparison of spectrophotometric, fluorometric, and highperformance liquid chromatography methods and estimation of detrital DNA. Appl environ microbiol, 1998;64:3238-45.

Donadio S, Monciardini P, Alduina R, Mazza P, Chiocchini C, Cavaletti L, Sosio M, Puglia AM. Microbial technologies for the discovery of novel bioactive metabolites. J Biotechnol 2002;99:187-98.

Ehrenreich IM, Waterbury JB, Webb EA. Distribution and diversity of natural product genes in marine and freshwater cyanobacterial cultures and genomes. Appl Environ Microbiol 
$2005 ; 71: 7401-7413$.

Falkowski PG, de Vargas C. Shotgun sequencing in the sea: a blast from the past? Sci, $2004 ; 304: 58-60$.

Faulkner J. Marine natural products. Nat Prod Rep 2002;19:1-48.

Fieseler L, Horn M, Wagner M, Hentschel U. Discovery of the novel candidate phylum 'Poribacteria' in marine sponges. Appl Environ Microbiol 2004;70:3724-32.

Fox GE, Pechman KR, Woese CR. Comparative cataloging of $16 \mathrm{~S}$ ribosomal ribonucleic acid: molecular approach to prokaryotic systematics. Lit J Syst Bacteriol 1977;27:44-57.

Friedrich AB, Fischer I, Proksch P, Hacker J, Hentschel U. Temporal variations of the microbial community associated with the Mediterranean sponge Aplysina aerophoba. FEMS Microbio Ecol 2001;38:105-113.

Funayama N. Nakatsukasa M. Kuraku S. Takechi K. Dohi M. Iwabe N. Miyata T. Agata K. Isolation of Ef silicatein and Ef lectin as molecular markers for sclerocytes and cells involved in innate immunity in the freshwater sponge Ephydatia fluviatilis. Zoolog Sci $2005 ; 22: 1113-1122$.

Gamulin V, Müller IM, Müller WEG. Sponge proteins are. more similar to those of Homo sapiens than to Caenorhabditis. elegans. Biol J Linn Soc 2000;71:821-8.

Geets J, Vangronsveld J, Diels L, van der Lelie D. The Application of Molecular Tools to Follow up Bioremediation. J Soil Sediments 2003;3:251. 
Gibbs SP. The chloroplasts of some algal groups may have evolved from endosymbiotic eukaryotic algae. Ann NY Acad. Sci 1981;361:193-208.

Giovannoni SJ. Genome streamlining in a cosmopolitian oceanic bacterium. Sci 2005;309:1242-5.

Goffredi SK, Jones WJ, Scholin CA, Marin R, Vrijenhoek RC. Molecular detection of marine invertebrate larvae. Mar Biotechnol (NY) 2006;8:149-60.

Gokhale RS, Tuteja D. Biochemistry of polyketide synthases. Biotechnology 2001;10:34172.

Haefner B. Drugs from the deep: marine natural products as drug candidates. Drug Discovery Today 2003;8:536 - 544 .

Haig SM. Molecular contributions to conservation. Ecol 1997;79:413-25.

Hellberg ME, Burton RS, Neigel JE, Palumbi SR. Genetic assessment of connectivity among marine populations. Bull Mar Sci 2002;70:273-90.

Hench LL. West JK. The sol-gel process. Chem Rev 1990:90:3372-3383.

Hentschel U, Schmid M, Wagner M, Fieseler L, Gernert C, Hacker J. Isolation and phylogenetic analysis of bacteria with antibacterial activities from the Mediterranean sponge Aplysina aerophoba and Aplysina cavernicola. FEMS Microb Ecol 2001;35:305312.

Hentschel J, Hopke J, Horn M, Friedrich AB, Wagner M, Hacker J, et al. Molecular evidence for a uniform microbial community in sponges from different oceans. Appl Environ Microbiol 2002;68:4431-40. 
Hirabayashi J, Kasai K. The family of metazoan metal-independent ß-galactoside-binding lectin: structure, function and molecular evolution Glycobiol 1993;3:297-04.

Holden M, Thomson N, Bentley S. Microbial mariners Nat Rev Microbiol 2005;3:748-749.

Holley $\mathrm{P}$, Whitehead $\mathrm{M}$. The genetics and molecular biology of marine fungi. Mycologist 2006;20:144-151.

Hugenholtz P. Impact of culture independent studies on the emerging phylogenetic view of bacterial diversity. J Bacteriol 1998;180:4765-74.

Kaluzhnaya OV, Belikov SI, Schroder HC, Wiens M, Giovine M, Krasko A, Muller IM, Muller WEG. Dynamics of skeleton formation in the Lake Baikal sponge Lubomirskia baicalensis Part II. Molecular biological studies. Naturwissenschaften 2005;92:134-138.

Kannan N, Taylor SS, Zhai Y, Venter JC, Manning G. Structural and functional diversity of the microbial kinome. PLoS Biol 2007;5:e17.

Keller M, Zengler K. Tapping into microbial diversity. Nat Rev Microbiol 2004;2:141-50.

Kim TK, Garson MJ, Fuerst JA. Marine actinomycetes related to the 'Salinospora' group from the Great Barrier Reef sponge Pseudoceratina clavata. Environ Microbiol 2005;7:509-18.

Kim JH, Waterman MS, Li LM. Diploid genome reconstruction of Ciona intestinalis and comparative analysis with Ciona savignyi. Genome Res 2007;17:1101-10.

Krasko A. Batel R. Schröder HC. Müller IM. Müller WEG. Expression of silicatein and collagen genes in the marine sponge Suberites Domuncula is controlled by silicate and 
myothrophin. Eur J Biochem 2000;267:4878-4882.

Li A, Piel JA. A gene cluster from a marine Streptomyces encoding the biosynthesis of the Aromatic spiroketal Polyketide Griseorhodin A. Chem Biol 2002;9:1017-26.

Li X, Qin L. Metagenomics-based drug discovery and marine microbial diversity. Trends Biotechnol 2005;23:539-43.

Li Z, He L, Wu J, Jiang Q. Bacterial community diversity associated with four marine sponges from the South China Sea based on 16S rDNA-DGGE fingerprinting. J Exp Mar Biol Ecol 2006;329:75-85.

Lindley D, Tabery J. "Molecular Biology", The Stanford Encyclopedia of Philosophy, Edward N. Zalta (ed.), 2005 available online at Molecular Biology (http://plato.stanford.edu/entries/molecular-biology/).

Long PF, Dunlap WC, Battershill CN, Jaspars M. Shotgun cloning and heterologous expression of the patellamide gene cluster as a strategy to achieving sustained metabolite production. ChemBioChem 2005;6:1-7.

Lopez JV, McCarthy PJ, Janda KE, Willoughby R, Pomponi SA. Molecular techniques reveal wide phyletic diversity of heterotrophic microbes associated with Discodermia spp. (Porifera: Demospongia). Memoirs of the Queensland Museum 1999;44;329-41 ISSN 0079-8835.

Mayer AMS, Rodríguez AD, Berlinck RGS, Hamann MT. Marine pharmacology in 2003-4: Marine compounds with anthelmintic antibacterial, anticoagulant, antifungal, antiinflammatory, antimalarial, antiplatelet, antiprotozoal, antituberculosis, and antiviral activities; affecting the cardiovascular, immune and nervous systems, and other miscellaneous mechanisms of action. Comparative Biochemistry and Physiology Part C: 
Toxicology \& Pharmacology 2007;145:553-81.

Mayer AMS, Gustafson KR. Marine Pharmacology in 2003-4: antitumor and cytotoxic compounds. Eur J Cancer 2006;43:2241-70.

Medlin LK, Kooistra WC, Schmid AM. A review of the evolution of the diatoms: a total approach using molecules, morphology and geology. In: Witkowski A., Sieminska, J., editors. The Origin and Early Evolution of the Diatoms: Fossil, Molecular and Biogeographical Approaches. W. Szafer Institute of Botany, Polish Academy of Sciences, Cracow, Poland. 2000. pp. 13-35.

Menezes MR, Ikeda M, Taniguchi N. Genetic variation in skipjack tuna Katsuwonus pelamis (L.) using PCR-RFLP analysis of the mitochondrial DNA D-loop region. J Fish Biol 2006; 68:156-161.

Miralto A, Barone G, Romano G, Poulet SA, lanora A, Russo GL, et al. The insidious effect of diatoms on copepod reproduction. Nature 1999;402:173-76.

Molecular biology in marine science: scientific questions, technological approaches and practical implications. Committee on molecular Marine biology, Ocean studies board, National Research Council , National Academy Press, Washington, D.C. 1994 (http://www.nap.edu/catalog.php?record_id=9119\#toc).

Moore BS. Biosynthesis of marine natural products: microorganisms (Part A). Nat Prod Rep 2005;22:580-593.

Moreira D, Rodriguez VF, Lopez GP. Analysis of a genome fragment of a deep-sea uncultivated Group II euryarchaeote containing 16S rDNA, a spectinomycin-like operon 
and several energy metabolism genes. Environ. Microbiol 2004;6:959-69.

Morris RM. Environmental genomics: exploring ecological sequence pace. Curr Biol 2006;16:R499-R01

Müller WEG, Conrad J, Zahn RK, Stteffen R, Uhlenbruck G, Müller I. Cell adhesion molecules in the hexactinellid Aphrocallistes vastus: species-unspecific aggregation factor. Differentiation 1984;26:30-35.

Müller Cl, Blumbach B, Krasko A, Schröder HC. Receptor protein-tyrosine phosphatases: origin of domains (catalytic domain, Ig-related domain, fibronectin type III module) based on the sequence of the sponge Geodia cydonium. Gene 2001;262:221-30

Müller WEG, Brümmer F, Batel R, Müller IM., Schröder HC. Molecular biodiversity. Case study: Porifera (sponges). Naturwissenschaften 2003;90:103-20.

Naish KA, Park LK. Linkage relationships for 35 new microsatellite loci in chinook salmon Oncorhynchus tshawytscha. Anim Genet 2002;33:316-8.

Newman DJ, Cragg GM. Marine natural products and related compounds in clinical and advanced preclinical trials. J Nat Prod 2004;67:1216-38.

Pfeifer K, Hassemann M, Gamulin V, Bretting H, Fahrenholz F, Müller WEG. S-type lectins occur also in invertebrates: High conservation of the carbohydrate recognition domain in the lectin genes from the marine sponge Geodia cydonium. Glycobiol 1993;3:179-84.

Pozzolini M. Strula L. Cerrano C. Bavestrello G. Camardella L. Parodi AM. Raheli F. Bennati U. Müller WEG. Giovine M. Molecular cloning of silicatein gene from marine 
sponge Petrosia ficiformis (Porifera, Demospongiae) and development of primmorphs as a model for biosilification studies. Mar Biotech 2004;6:594-603.

Preston CM, Wu KY, Molinski TF, DeLong EF. A psychrophilic crenarchaeon inhabits a marine sponge: Cenarchaeum symbiosum gen. nov., sp. nov. Proc Natl Acad Sci U S A 1996;93:6241-46.

Qiao D, Nikitina LA, Buznikov GA, Lauder JM, Seidler FJ, Slotkin TA. The sea urchin embryo as a model for mammalian developmental neurotoxicity: ontogenesis of the high-affinity choline transporter and its role in cholinergic trophic activity. Environ Health Perspect 2003;111:1730-5.

Ramaiah N, Chun J, Ravel J, Straube WL, Hill RT, Colwell RR. Detection of luciferase gene sequences in nonluminescent bacteria from the Chesapeake Bay. FEMS Microbiol Ecol 2000a; 33:27-34.

Ramaiah N, Hill RT, Chun J, Ravel J, Matte MH, Straube WL, Colwell RR. Use of a chiA probe for detection of chitinase genes in bacteria from the Chesapeake Bay FEMS Microbiol Ecol 2000b;34:63-71.

Rast JP, Amore G, Calestani C, Livi CB, Ransick A, Davidson EH. Recovery of developmentally defined gene sets from high-density cDNA macroarrays. Dev Biol 2000;228:270-86.

Rast JP, Cameron RA, Poustka AJ, Davidson EH. Brachyury target genes in the early sea urchin embryo isolated by differential macroarray screening. Dev Biol 2002;246:191-08. 
Rast JP, Smith LC, Loza-Coll M, Hibino T, Litman GW. Genomic insights into the immune system of the sea urchin. Sci 2006;314:952-956

Rawat DS, Joshi MC, Joshi P Atheaya H. Marine peptides and related compounds in clinical trial. Anti-Cancer Agents - Med Chem 2006;6:1-8.

Redfield AC. The biological control of chemical factors in the environment. Am Sci 1958;46:205-21.

Riesenfeld CS, Schloss PD, Handelsman J. Metagenomics: genomic analysis of microbial communities. Annu Rev Genet 2004;38:525-52.

Rocha-Olivares A. Multiplex haplotype-specific PCR: a new approach for species identification of the early life stages of rockfishes of the species-rich genus Sebastes Cuvier. J Exp Mar Biol Ecol 1998;231:279-290.

Roche JL, McKay RML, Boyd P. Immunological and molecular probes to detect phytoplankton responses to environmental stress in nature. Hydrobiologia 1999;401:177-198.

Rondon MR, August PR, Bettermann AD, Brady SF, Grossman TH, Liles MR, et al. Cloning the soil metagenome: a strategy for accessing the genetic and functional diversity of uncultured microorganisms. Appl Environ Microbiol 2000;66:2541-47. 
Scala S, Carels N, Falciatore A, Chiusano ML, Bowler C. Genome properties of the diatom phaeodactylum tricornutum. Plant Physiology 2002;129:993-1002.

Schmidt HA, Strimmer K, Vingron M, von Haeseler A. TREE-PUZZLE: maximum likelihood phylogenetic analysis using quartets and parallel computing. Bioinformatics 2002;18:502-504.

Sea Urchin Genome Sequencing Consortium. The genome of the sea urchin Strongylocentrotus purpuratus. Science 2006;314:941 -952.

Seo HC, Kube M, Edvardsen RB, Jensen MF, Beck A, Spriet E, Gorsky G, Thompson EM, Lehrach $H$, Reinhardt $R$, Chourrout D. Miniature genome in the marine chordate Oikopleura dioica. Science 2001;294: 2506.

Shimizu K, Cha J, Stucky GD, Morse DE. Silicatein Alpha: Cathepsin L-Like Protein In Sponge Biosilica, Proc Natl Acad Sci USA 1998;95:6234-6238.

Simmen MW, Leitgeb S, Clark VH, Jones J, Bird A. Gene number in an invertebrate chordate, Ciona intestinalis. Proc Natl Acad Sci USA 1998;95:4437-40.

Sipkema D, Franssen MC, Osinga R, Tramper J, Wijffels RH. Marine sponges as pharmacy. Mar Biotechnol 2005;7:142-62.

Speel EJM, Hopman AHN, Komminoth P. Amplification Methods to Increase the Sensitivity of In Situ Hybridization: Play CARD(S). J Histochem Cytochem 1999;47:281-88.

Stober W. Fink A. Bohn E. Controlled growth of monodisperse silica spheres in the micron size range. J Colloid Interface Sci 1968;26:62-69.

Sudek S, Lopanik NB, Waggoner LE, Hildebrand M, Anderson C, Liu H, Patel A, Sherman DH, Haygood MG. Identification of the Putative Bryostatin Polyketide Synthase Gene 
Cluster from "Candidatus Endobugula sertula", the Uncultivated Microbial Symbiont of the Marine Bryozoan Bugula neritina. J Nat Prod 2007;70:67 -74.

Tan LT. Bioactive natural products from marine cyanobacteria for drug discovery. Phytochem 2007;68:954-79.

Taylor MW, Schupp PJ, Dahllöf I, Kjelleberg S, Steinberg PD. Host specificity in marine sponge-associated bacteria, and potential implications of marine microbial diversity. Environ Microbiol 2004;6:121-30.

Taylor MW, Schupp PJ, de Nys R, Kjelleberg S, Steinberg PD. Biogeography of bacteria associated with the marine sponge Cymbastela concentrica. Environ Microbiol $2005 ; 7: 419-33$.

Thakur NL, Hentschel U, Krasko A, Pabel CT, Anil AC, Müller WEG. Antibacterial activity of the sponge Suberites domuncula and its primmorphs: potential basis for epibacterial chemical defense. Aquat Microb Ecol 2003;31:77-83.

Thakur NL, Perovic'-Ottstadt S, Batel R, Korzhev M, Diehl-Seifert B, Müller IM Müller WEG. Innate immune defense of the sponge Suberites domuncula against grampositive bacteria: induction of lysozyme and AdaPTin. Mar Biol 2005;146:271-82.

Thakur NL, Müller WEG. Sponge-bacteria association: A useful model to explore symbiosis in marine invertebrates. Symbiosis 2005;39:109-116.

Tolbert SH. Firouzi A. Stucky GD. Chmelka BF. Magnetic field alignment of ordered silicate-surfactant composites and mesoporous silica. Science 1997; 278:264-268. 
Van Den Hoek C. Mann DG. Johns HM. Algae: An Introduction to Phycology. Cambridge University Press, London 1997.

Venter JC, Remington K, Heidelberg JF, Halpern AL, Rusch D, Eisen JA et al. Environmental Genome Shotgun Sequencing of the Sargasso Sea. Science 2004;304:66 -74.

Wagner M, Smidt H, Loy A, Zhou J. Unravelling Microbial Communities with DNAMicroarrays: Challenges and Future Directions, Microb Ecol 2007 (in press).

Ward DM, Bateson MM, Weller R, Ruff-Roberts AL. Ribosomal RNA analysis of microorganisms as they occur in nature. Adv Microb Ecol 1992;12:219-86.

Webb VL, Maas EW. Sequence analysis of 16S rRNA gene of cyanobacteria associated with the marine sponge Mycale (Carmia) hentscheli. FEMS Microbiol Lett 2002;207:437.

Weaver JC, Morse DE. Molecular biology of demosponge axial filaments and their role in biosilicification. Micr Res Techn 2003;62:356-367.

Webster NS, Wilson KJ, Blakcall LL, Hill RT. Phylogenetic diversity of bacteria associated with marin sponge Rhopaloeides odorabile. Appl Enviro. Microbial 2001;67:434-44.

Wilson K, Thorndyke M, Nilsen F, Rogers A, Martinez P. Marine systems: moving into the genomics era. Mar Ecol, 2005;26:3-16.

Wiens M, Lukic L, Mueller WEG, Gamulin V. Ubiquitins (Polyubiquitin and Ubiquitin extension protein ) in marine sponges: cDNA sequence and phyligenetic analysis. Biol $\mathrm{J}$ 
Linnean Soc 1999;67:43-56.

Wiens M. Belikov SI. Kaluzhnaya OV. Krasko A. Schroder HC. Perovic-Ottstadt S. Muller WEG. Molecular control of serial module formation along the apical-basal axis in the sponge Lubomirskia baicalensis: silicateins, mannose-binding lectin and mago nashi. Dev Genes Evol 2006;216:229-242. 


\section{Legends for figures}

Figure 1. Schematic representation of $16 \mathrm{~S}$ rDNA library construction of marine sponge-associated bacteria. Following sponge DNA extraction PCR amplification of bacteria specific 16S rRNA gene is performed. PCR product is cloned in a suitable vector and generated plasmids are sequenced. Sequences are used to construct phylogenetic trees. This technique provides valuable information about the diversity of sponge-associated bacteria without culturing them.

Figure 2. Schematic representation of Denaturing Gradient Gel Electrophoresis (DGGE) procedure. Following sponge DNA extraction, a PCR reaction is performed. One 16S rRNA primer in the reaction contains a GC-clamp. The PCR reaction mixture is separated into individual bands on a polyacrylamide gel with an increasing denaturing gradient that includes urea and formamide. The GCclamp acts as an 'anchor' and ensures that each PCR product is not separated into single strands during migration in the gel. Here, each DGGE band represents a single 16S rRNA gene sequence. Thus each lane represents a fingerprint of a sponge microbial community at a given time.

Figure 3. Schematic representation of Restriction Fragment Length Polymorphism (RFLP) protocol. DNA obtained from marine bacteria is digested with restriction enzyme and band pattern is checked on agarose gel. In a second procedure, 16S rRNA gene is amplified from bacterial DNA and PCR product is digested to check RFLP pattern.

Figure 4. Schematic representation of metagenomic library preparation from marine environmental samples. 


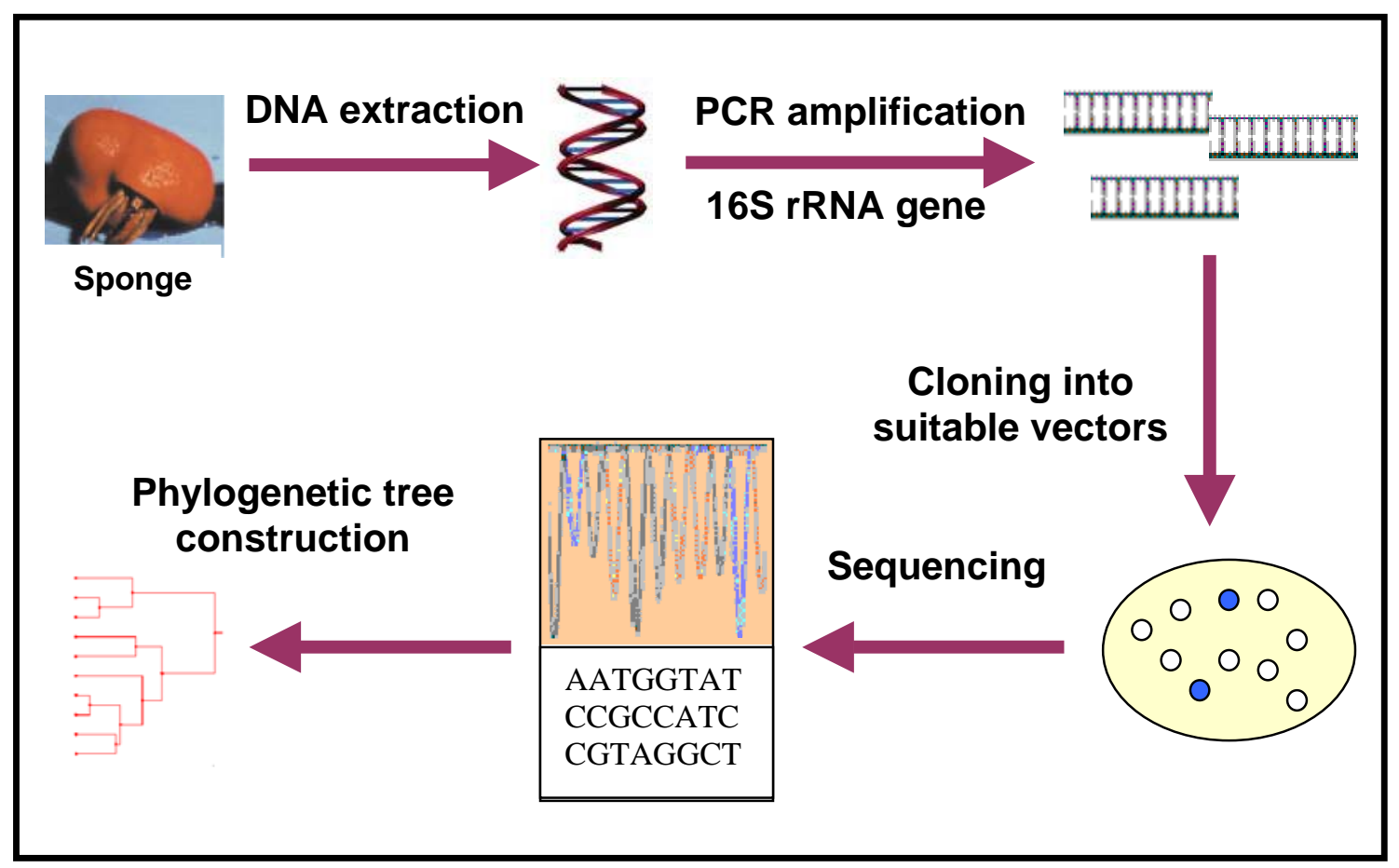

Figure 1. 


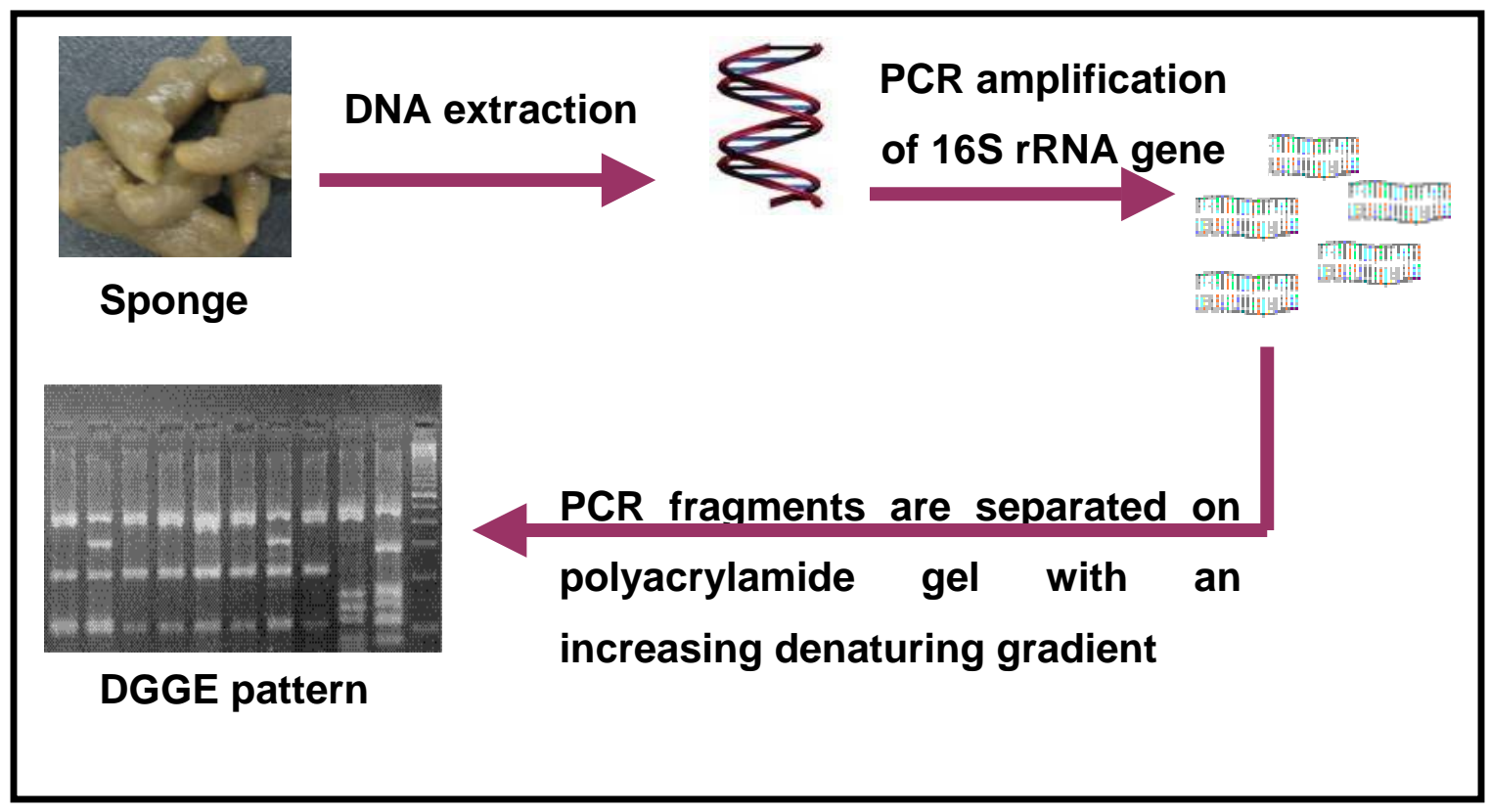

Figure 2. 


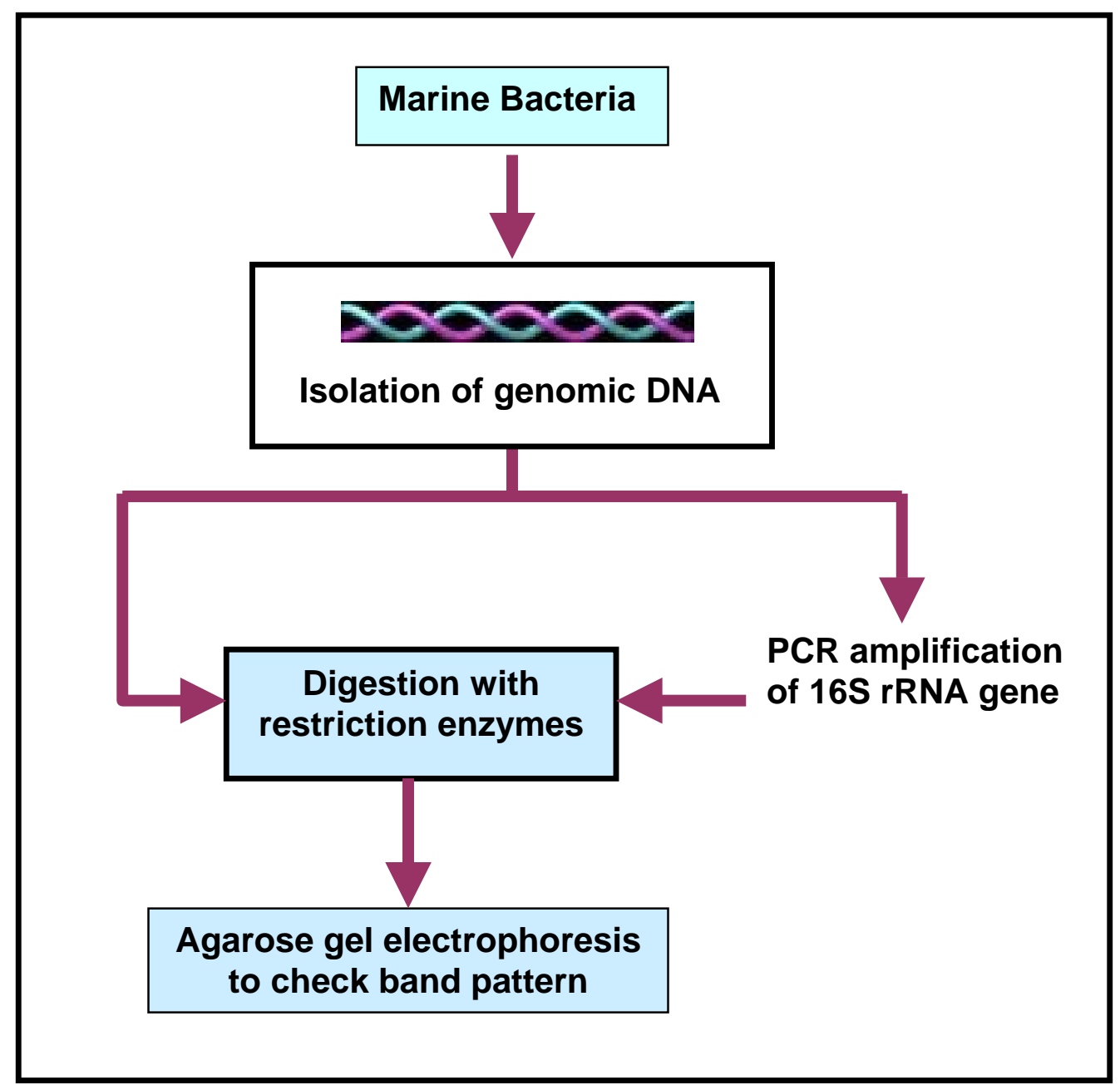

Figure 3 


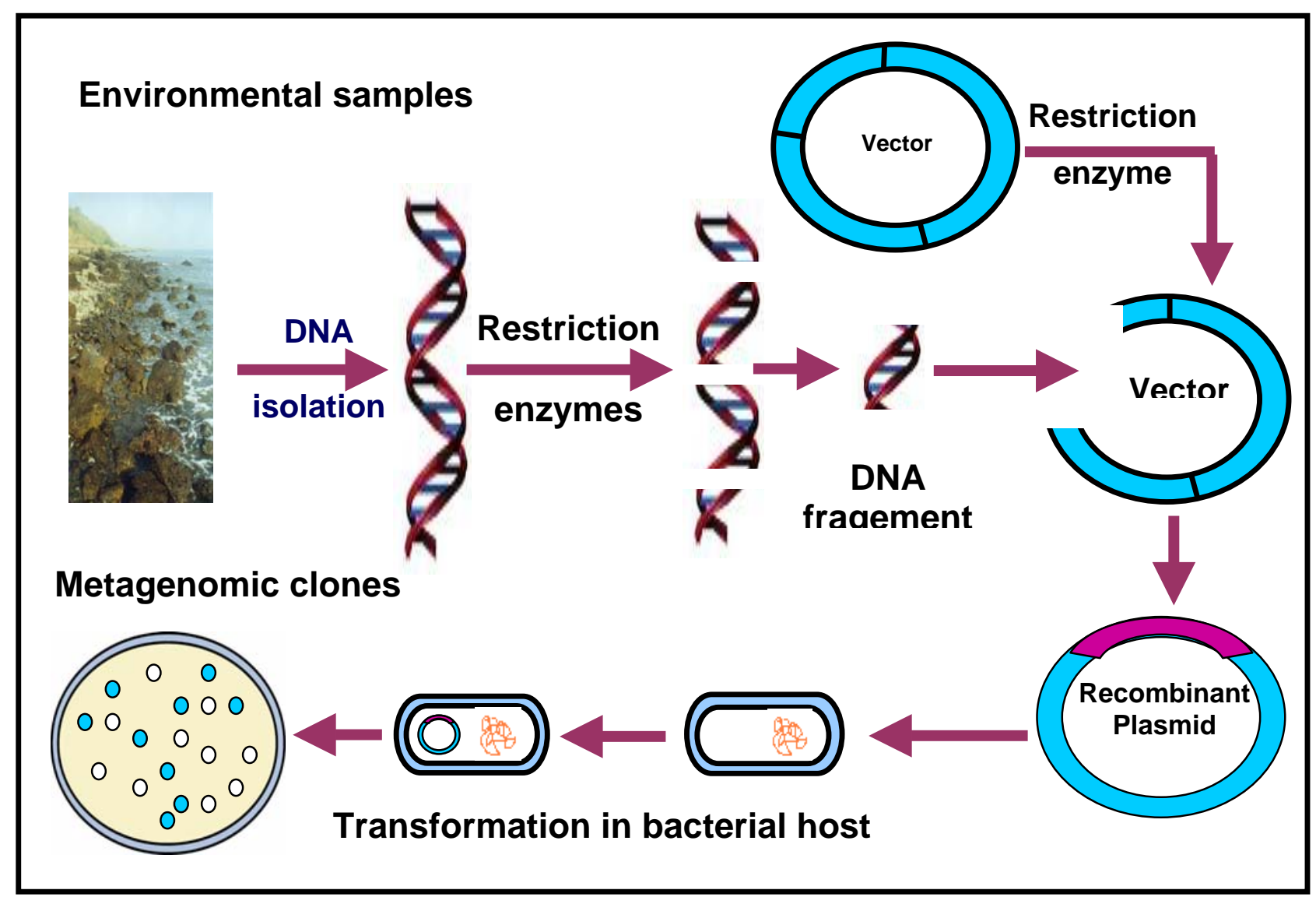

Figure 4. 